\title{
Panoramic Memory, Affect, and Sensations of Detachment in the Dying: Discussions Published in France, 1889-1903
}

\author{
Carlos S. Alvarado, Ph.D. \\ Atlantic University
}

\begin{abstract}
Between 1889 and 1903, several authors published papers in the French journal Revue Philosophique de la France et de l'Étranger and in a few other publications in which they discussed panoramic memory, changes of affect, and a sense of detachment from the body in dying persons. With a few exceptions these publications have been ignored in modern discussion of the phenomena of the dying. Whereas philosopher Victor Egger postulated the psychological explanation that panoramic memory results from the dying person's thoughts of imminent death, physicians Paul Sollier and Charles Féré and psychologist Henri Piéron proposed that it, as well as changes in affect, result from physiological changes in the body sensibility and in the brain. Like many authors today who speculate about near-death experiences, the authors in question did not have much evidence for their explanations. These ideas, and their physiological aspects, were part of a general interest in unusual phenomena and states of consciousness during the 19th century.
\end{abstract}

KEYWORDS: life review; panoramic memory; near-death experiences; drowning; Victor Egger; Charles Féré; Paul Sollier; Henri Piéron

In 1896 well-known student of psychopathology, Pierre Janet (18591947), commented in the pages of the Revue Neurologique about an article the author of which discussed "the often reported fact that

Carlos S. Alvarado, Ph.D., is Scholar in Residence at Atlantic University. The author thanks the Society for Psychical Research for financial support and is grateful to Nancy L. Zingrone, Bruce Greyson, and Janice Holden for useful editorial suggestions for the improvement of this article. Reprint requests should be addressed to Dr. Alvarado at Atlantic University, 215 67th Street, Virginia Beach, VA 23451; email: carlos.alvarado@atlanticuniv.edu. 
the drowned facing imminent death review their whole life in an instant" (Janet, 1896, p. 245; this and other translations in this article are mine). The author in question, French philosopher Victor Egger (1848-1909), started a discussion about sensations of detachment in the dying and what current scholars refer to as panoramic memory that other authors continued and that current scholars of near-death experiences (NDEs) and related phenomena are likely to find interesting. Although the work of Egger has been referenced by some French writers (e.g., Le Maléfan, 1995; Poulet, 1963, pp. 165-205), his writings, and those of the other persons discussed in the present article, have not been cited in general overviews of NDEs (e.g., Agrillo, 2011; Blackmore, 1993; Bonilla, 2011; Greyson, 2000) nor in discussions of theoretical models (Greyson, Kelly \& Kelly, 2009) and of the history of the subject (Holden, Greyson, \& James, 2009, pp. 2-3). Furthermore, with a few exceptions (Biondi, 2010; Bozzano, 1931, pp. 50-97), writers about panoramic memories have also neglected such publications (e.g., Stevenson \& Cook, 1995). This situation may be explained by the fact that the papers in question appeared only in French and that they were published in difficult-to-obtain journals, something that is starting to change with the development of virtual libraries (e.g., Alvarado, 2010).

The purpose of this current article is to discuss Egger and other largely forgotten French writers who, between 1889 and 1903, published about cases of panoramic memory, changes of affect, and floating sensations in the dying. I focus specifically on this period because it was during this particular 15-year span that certain authors published certain ideas of possible relevance to contemporary scholars in the field of near-death studies but of which they may not be aware. Rather than present detailed evaluation of the validity of these writings and comparisons to more recent ideas, my purpose is to summarize the ideas of these writers so as to bring them to the attention of contemporary students of NDEs.

\section{Interest in Unusual Experiences and in Reports of Phenomena of the Dying}

The discussions about panoramic memory presented here were embedded in a variety of intellectual concerns prevalent during the 19th century. One of them was interest in unusual mental states and phenomena such as mesmeric somnambulism, mediumship, ambulatory 
automatisms, double and multiple personality, and sensory and motor hysterical disturbances. Such topics informed a variety of scholars, scientists, and others about the existence of alterations of consciousness and dissociative phenomena (Cardeña \& Alvarado, 2011; Castel, 1998; Crabtree, 1993).

Another topic of relevance was concern with misunderstood memory phenomena, a topic discussed in such well-known books as Inquiries Concerning the Intellectual Power and the Investigation of Truth (Abercrombie, 1832), On Obscure Diseases of the Brain, and Disorders of the Mind (Winslow, 1860), and Les Maladies de la Mémoire (Ribot, 1881). In the last mentioned book philosopher and psychologist Théodule Ribot (1839-1916) wrote on hypermnesia, or exaltation of memories, pointing out that they sometimes took place during acute fevers, ecstacy, hypnosis, and drowning (Ribot, 1881). These and other issues, and particularly the theoretical ideas and empirical observations concerning hysteria and hypnosis, were important catalyzers in the development of French psychology and psychiatry (Foschi, 2003; Nicolas, 2002).

Another intellectual context for the topic of this paper, and a more direct one, was discussions about death. During the 19th century, like in other periods of human history, many authors published books about death and the experiences of the dying. One example is English physician William Munk's (1816-1898) Euthanasia: Or Medical Treatment in Aid of an Easy Death (1887); others include Clarke (1878), Cobbe (1877), Is Death Painful? (1870), and Lauvergne (1842). In addition, authors discussed what scholars now call NDEs (e.g., Heim, 1892; Myers, 1892; Wiltse, 1889; Winslow, 1860). English classical scholar and psychical researcher Frederic W. H. Myers (1843-1901) stated: "It is possible that we might learn much were we to question dying persons, on their awakening from some comatose condition, as to their memory of any dream or vision during that state" (1892, p. 180).

One writer commented that in some experiences coming close to death, the person "has a complete recollection of its early existence from beginning to end ..." (Jung-Stilling, 1808/1834, p. 62). Nineteenth-century examples of these experiences, later called panoramic memory and life review, were those taking place during falls (Francis, 1896, p. 216; Head, 1860, p. 47; Heim, 1892), war injuries (Derepas, 1883 , p. 203), and hanging (Winslow, 1860, pp. 440-441). More relevant to Egger's publications were examples of this phenomenon reported by individuals that survived drowning (e.g., Barrow, 1847, pp. 398-403; Binns, 1842, pp. 271-272; De Quincy, 1864, pp. 234- 
235; de V., 1893; O., 1855; S., 1868). One of the most remarkable descriptions of this experience was written by the Irish Admiral Francis Beaufort (1774-1857), who survived drowning:

Though the senses were thus deadened, not so the mind; its activity seemed to be invigorated, in a ratio which defies all description-for thought rose after thought with a rapidity of succession that is not only indescribable, but probably inconceivable, by any one who has not himself been in a similar situation. The course of those thoughts I can even now in a great measure retrace-the event which had just taken place-the awkwardness that had produced it-the bustle it must have occasioned (for I had observed two persons jump from the chains) - the effect it would have on a most affectionate father- the manner in which he would disclose it to the rest of the family - and a thousand other circumstances minutely associated with home, were the first series of reflections that occurred. They took then a wider range - our last cruise - a former voyage, and shipwreck-my school-the progress I had made there, and the time I had misspentand even all my boyish pursuits and adventures. Thus travelling backwards, every past incident of my life seemed to glance across my recollection in retrograde succession; not, however, in mere outline, as here stated, but the picture filled up with every minute and collateral feature; in short, the whole period of my existence seemed to be placed before me in a kind of panoramic review, and each act of it seemed to be accompanied by a consciousness of right or wrong, or by some reflection on its cause or its consequences; indeed, many trifling events which had been long forgotten then crowded into my imagination, and with the character of recent familiarity (Barrow, 1847, pp. 399-400).

In fact these experiences during drowning seemed to have been common knowledge, being mentioned in medical reference works (e.g., Herold, 1898, p. 382; Rosse, 1894, p. 800). An anonymous author commented:

One of the most singular features in Psychology is the fact which is perfectly notorious, that the faculty of memory acquires an activity and tenacity in the cases of persons about being drowned, which it never exhibits under ordinary circumstances (Memory, 1853, p. 250).

The experience was also mentioned in literary works, such as in the following passage written by George Eliot (1819-1880): "The drowning man, urged by the supreme agony, lives in an instant through all his happy and unhappy past: when the dark flood has fallen like a curtain, memory, in a single moment, sees the drama acted over again" (1858, p.151). These memory images of the dying were inter- 
esting enough to be featured in 19th century magazines and journals such as the American and Continental Journal (Buffet, 1870), the National Magazine (Sensations of Drowning, 1853), and the British Medical Journal (What Drowning Feels Like, 1894).

The topic was also mentioned by those interested in psychic phenomena. In his book Man and His Relations, Universalist minister and spiritualist Samuel B. Brittan (1815-1883) noticed the existence of cases in drowning in which "under the apprehension of immediate death, the mind acts with such incredible rapidity that the whole history of the drowning man passes before him in a single moment" (1854, p. 84, footnote). Similarly, physician George Wyld (1821-1906) wrote in the spiritualist journal Light that the "all but drowned man has often flashed before his mental vision the past, and present, and future of his life ..." (1881, p. 68).

\section{French Discussions of Panoramic Memory, Affect, and Sensations of Detachment in the Dying}

Most of the papers to be discussed in this section appeared in the French journal Revue Philosophique de la France et de l'Étranger. Founded in 1876 by Théodule Ribot, the journal was devoted to psychology, philosophy, sociology, and other social sciences and, like other works by the author, was very influential. A significant part of the new empirical psychology, represented by Ribot (1870) himself, was articulated and publicized in this journal (Meletti Bertolini, 1991). The publication served as a forum that did much to encourage the study of unusual states of consciousness, as seen in important papers discussing hypnosis and dissociative phenomena in general (e.g., Janet, 1886; Richet, 1883). In addition, the journal published some papers about parapsychological phenomena, among them Charles Richet's (1850-1935) well-known and widely-cited article about mental suggestion, "La Suggestion Mentale et le Calcul des Probabilités" (Richet, 1884; see Alvarado, 2008). Considering the openness of this publication to unusual phenomena and its emphasis on the empirical study and analysis of psychological phenomena, it is not surprising that it carried the papers discussed below. 


\section{Victor Egger}

Before he published his work about the dying, Victor Egger had written about physiological approaches to psychology, mistakes of vision, and dreams (see, respectively, Egger, 1877, 1878, 1895). He was particularly known for his interest in introspection, as seen in his book entitled La Parole Intérieure (1881) in which he argued that human beings always carried an internal dialogue. This dialogue, part of human actions and other mental phenomena, represented a "considerable part of the consciousness of every one of us" (p. 1). His analysis included imagery and phenomena such as the hallucinations of Socrates and Jeanne d'Arc. This internal life was explored further in some of his later publications and was part of the French interest in introspection that started to decline in the late 19th century (Brooks, 1998).

In 1895 Egger published an article about dreams in which he referred in passing to "panoramic memory" in a case of drowning. As he wrote, "I imagine that the idea of imminent death may induce a very vivid sense of the self that will cease to exist ...." (p. 55).

In a later paper, Egger (1896a) mentioned several published cases of panoramic memory occurring to persons close to death and included a brief mention of the work and experiences of Swiss geologist and alpinist Albert Heim (1849-1937), as reported in a French newspaper (Egger, 1896a, p. 27; see Heim, 1892, and Noyes \& Kletti, 1972). In his view, if being close to death produced a strong fear of death, the state was equivalent to a "definitive or temporary death" (Egger, 1896a, p. 27). However, he was skeptical of people who claimed that they had seen all the events of their earlier lives, a claim he considered to be an exaggeration. If death came suddenly, people could develop "concepts and propositions" (p. 30) related to their mortality. The recollections, Egger postulated, represented the "self that is going to end" (p. 30). Their appearance into consciousness meant that that they were produced by the sudden idea of an "imminent death" (p. 30). According to Egger, in some people the self may resist the approach of death. But if they felt death could not be prevented, they were more open to memory images.

In children, Egger (1896a) continued, the sense of self was less developed than in adults. Consequently, children did not experience this phenomenon. Adults, and particularly older people, were more susceptible to panoramic memories because their sense of self was more developed than that of younger people. Egger believed that closeness 
to death produced what he referred to as a "live self," consisting of "significant and rapid images" (p. 37).

\section{Paul August Sollier}

After Egger's (1896a) paper was published, the Revue received three letters by authors commenting on the article. Two of them presented further cases of panoramic memory (Keller, 1896; Mouilin, 1896). The French physician Paul August Sollier (1861-1933; see Bogousslavsky \& Walusinski, 2011), who had published on a variety of medical topics such as amnesia (Sollier, 1892) and mental illness (Sollier, 1893), insisted that Egger's cases did not involve real death but instead the belief one was going to die (Sollier, 1896). He wrote, "the psychological phenomena that M. Egger tries to explain are connected to the idea that death is coming, but not to the start of death" (Sollier, 1896, p. 304). In his view it was important to know whether there was an organic condition that could cause death or whether or not the case was one in which some exterior circumstance could cause death, such as an accident.

Sollier (1896) presented some cases of drug addicts whom he had observed while they were dying. He noticed that they felt a sensation of detachment from everything as the end approached. For example, he observed a young woman who was close to death on three separate occasions. Although no phenomena were reported in the first instance, the patient had a general sense of wellbeing-which Sollier sometimes called a state of beatitude-and experienced detachment in the second brush with death. On the third occasion, while suffering from peritonitis, she experienced images about her life in chronological order from her youth to her current state, "sort of an inventory of her self" (Sollier, 1896, p. 306).

Panoramic memory was explained by Sollier (1896) as follows. He argued that when an accident took place, all attention was focused on what may cause death. Such distraction induced anesthesia and analgesia, which in turn explained the sense of wellbeing experienced by some persons close to death. "But at the same time we make a violent effort to escape death" (p. 306). In this state, Sollier believed, one's senses gather information using all one's energy. As a by-product one's consciousness may be heightened, including the expression of "previously acquired elements" (p. 306) or memories.

Sollier (1896) postulated that a similar process takes place in physiological death. Weakness could cause sensory isolation, and the sense 
of self was "reduced to old impressions, the current organic impressions are ... annihilated" (p. 307).

Later, Sollier stated in his book Le Probleme de la Mémoire that strong emotions such as those evoked by accidents could trigger memories of facts that were not directly related to the event. An example was "panoramic recollections" when people were near death (Sollier, 1900, p. 208). He also mentioned the recollections of hysterics. In his view, in these cases "they are suddenly reviewing . . . in a real panorama, all their prior existence absolutely as . . people who drown" (1900, p. 209).

In a different article Sollier (1903) presented a case of a nervous young woman who was also a morphine addict. While in treatment for addiction, she experienced such symptoms as diarrhea and vomiting. At one point she experienced a sharp burning pain from the head to the back of the neck. Soon after this she had a sensation of wellbeing and:

she saw all her existence unfold; this state, she told me later, was as if all the incidents of her life had been printed on a cloth that unfolded the ups and downs [of her life] in front of her. The incidents succeeded in retrograde order, from today to the age of five or six years or less. "Everything I had on the head, I saw . . . in unparalleled details, accompanied with vague regrets and ... a sense of grief, never of joy . ..., everything was greyish ... things were flat; but some facts of my life, the emotions for example, were kind of in relief to me; it was as if you looked at three photographs of people that you knew well; two seemed to be flat and one that you love seems very clear and in great relief" (Sollier, 1903, p. 29).

When the patient recovered she was anxious, had a very vague feeling of herself, and was completely anesthetic. In addition, she showed contractions and loss of consciousness that she did not have before her crisis. In another occasion she had autoscopic hallucinations in which she saw an image of herself.

As he had argued in his previous paper, Sollier (1903) believed that the loss of sensibility explained both the appearance of the sense of wellbeing and the memory images. In his view: "Each personality state corresponds to a cerebral state, a particular potential. When the potential is reduced from what it is currently to zero, we pass forcefully through all the degrees of potential successively achieved, but in an inverse way" (Sollier, 1903, pp. 30-31). The images a person has are linked to different potential states of the brain, and they appear when this potential is lowered to states that correspond to the images. 
The images appear in retrograde order following a rapid change in potential.

In Sollier's view the process of recollection in syncopes (fainting episodes that may end in death) is similar to the regression of personality that takes place in hysteria. As he wrote: "The only difference is that, in the case of cerebral exhaustion, the potential is normal and falls from normal to zero, while in hysteria it is below normal and returns to its maximun" (Sollier, 1903, p. 31). But the end result is the same. That is, in both cases the brain presents successive states, a process that includes images of the self.

Sollier (1903) described phenomena taking place during therapy with this patient that he implied validated the above-mentioned explanation. During the treatment she showed "all her old personality states" (p. 31) consisting of recollections of images, actions, impressions, and emotions. Such phenomena referred to the patient's life after nine years of age, after which she started having her first nervous problems such as heart palpitations.

Egger (1896b) wrote a second paper in which he answered Sollier's (1896) first publication and presented new cases, some of them communicated to him directly by persons who had been close to death (e.g., drowning). He questioned Sollier's explanation assuming an "almost complete suppression of general sensibility" (p. 340). Egger argued that Sollier could not explain those cases of people in mortal danger who did not experience anesthesia. Furthermore, Egger said that all of Sollier's cases could be reinterpreted following the idea of imminent death taking hold of the mind of his patients. Such idea was the "necessary condition for the phenomena" to occur (p. 343).

Egger argued further that "imagination and thought are employed in a special direction" (p. 342) related to the idea of imminent death. Such an idea provoked "semi-logical reactions" (p. 342) in the experiencers. In his view, recollections of persons in the shock of being near death, including drowning, were "phenomena analogous to the dreams of sleep" (p. 368).

\section{Charles Féré}

Another French contributor to the debates was Charles Féré (18521907), well known for his work in hypnosis (Binet \& Féré, 1885) and in the interrelations of sensory and motor phenomena (Féré, 1887; on Féré, see Larner, 2011). Before the articles of Egger and Sollier had been published in the Revue, Féré had discussed the subject in 
two publications. In the first article he referred to the phenomenon of "reminiscence" in the dying as a neglected topic but a phenomenon that manifested in natural deaths and in epileptics (Féré, 1889). Sometimes this phenomenon of "panoramic representation" (p. 108) seemed to include all the existence of the individual, whereas on other occasions it included only a few seemingly unimportant events. In Féré's view the recollections represented a "brusque modification of cerebral circulation" (p. 109). Féré (1892) restated this explanation in his book, La Pathologie des Émotions. In his view: "The intellectual perversions that arise at the hour of death seem to be connected to certain circulation problems ...." (p. 170). Sudden modifications of cerebral circulation, he argued, could explain the reminiscences seen in drowning cases in which the person sees "unfolding in front of him the picture of his entire life" (p. 171).

In a later article in the Revue Philosophique de la France et de l'Étranger Féré (1898) revisited recollections of earlier life events and discussed euphoria close to the moment of death as well. In his view, separate from reacting to the idea of death, the "dying present psychic phenomena in direct relation to physical phenomena" (p. 298), which was also seen in the insane and in "idiots" when going through illnesses involving fever. At death, Féré stated, "the animal tissues and in particular the muscles and the nerves present a period of hyperexcitability in which, due to an equivalent excitation, its reactions are stronger than in the normal state" (p. 301). The brain, Féré believed, should pass through a similar process. As he wrote: "The glimmers of intelligence and euphoria of the dying can be explained by a physiological condition: a momentary hyperexcitability of the nervous elements ...." (p. 302) that makes those elements lose their usual properties. Féré stated that such process took place both in the "nervous central elements as in peripheral nerves" (p. 302). Furthermore, it was stated that the phenomena also depended on individual susceptibilities and aptitudes of the persons in question.

\section{Henri Piéron}

French experimental and physiological psychologist Henri Piéron (1881-1964; on Piéron see Reuchlin, 1964) classified the panoramic images in two types, those that were simultaneous and those that were successive and very fast (Piéron, 1901). In his view, images of the first type were probably illusory, and speed of images of the second type were exaggerated. He also speculated that these images came 
from the subconscious mind. In a note in the Revue Philosophique de la France et de l'Étranger, Piéron (1902) summarized a few cases of patients who had sensations of elevation or flying when close to death. He suggested that these sensations could be accounted for by postulating an "anesthesia of the part of the body lying on the bed" (p. 616) due to the slowing of circulation caused by prolonged lying down. Finally, Piéron (1903) noted that the evocation of images was not only associated with dying but with the belief one was going to die. In his view this evocation was due to a "sudden imposition of a focus of attraction of consciousness" that produced an "unforgettable illusion in all those observing the phenomenon" (p. 95).

\section{Discussion}

As argued previously, interest in panoramic memory was part of the general interest in France and elsewhere about abnormal psychology and unusual phenomena. This interest also included unusual memory manifestations and the experiences of the dying.

The authors I have discussed defended different explanatory models for the phenomena in question. Egger's approach was psychological, emphasizing the effect of the fear of death on panoramic memory. Sollier, Féré, and Piéron, on the other hand, followed physiological models. It must be recognized that such speculations, even when seen in the context of their times, were not based on good evidence. This situation has been typical of many attempts to explain near-death experiences during the last decades; for overviews see Greyson (2000) and Greyson, Kelly, \& Kelly (2009). This has also been the case with other phenomena. The history of psychological and physiological theory illustrates the tendency of some authors to defend interpretations that have very little empirical evidence in their support. Out-of-body experiences (Alvarado, 2009), hallucinations (Asaad, 1990), and depersonalization (Sierra \& Berrios, 1997) have been examples of this phenomenon.

In fact, psychologist Alfred Binet (1857-1911) reminded readers that both Egger's and Sollier's views were basically theoretical; he thereby implied a lack of empirical support (Binet, 1897, p. 635). Binet felt that Egger did not explain the fast flow of thoughts in persons who came close to death through accidents. He also criticized Sollier's contention that positive emotions were enhanced at death. In Binet's view, anesthesia and analgesia should produce negative emotions rather than positive ones. 
The physiologically-based explanations of Sollier, Féré, and Piéron were typical of 19th century attempts to explain thought and behavior through the functioning of the nervous system (Young, 1970). Similar explanations were proposed for hallucinations (Brierre de Boismont, 1845) and trance (Beard, 1877). In a discussion of the famous double personality case of Félida X. (b. 1843), it was speculated that the changes of memory and behavior were related to problems of cerebral circulation (Azam, 1893, pp. 63-64). Other authors presented similar speculations about mental illness in general (Lewis, 1889, pp. 129-130).

The topic of changes in sensibility was ever-present in the mind of the 19th century physician partly because of its association with hysteria (e.g., Janet, 1892; Richer, 1885, pp. 23-24). Writing about sleepwalking, a physician referred to the "suspension more or less complete of external feeling" (Prichard, 1850, p. 194). Binet hinted that the physical insensibility typical in "doubling" (dissociation) cases, in which two selves appeared to coexist, was assisted by a lack of sensation. That is, such insensibility could help one consciousness function without the interference of the other (Binet, 1892, p. 83). Similarly, Leuba (1902) stated that one of the main characteristics of the temperament of Christian mystics was the unstable nature of their "organic sensibility" - that is, that they alternated "between anesthesia and hyperesthesia" (p. 2).

Closer to the feeling of detachment and elevation that Sollier and Piéron mentioned was the notion of flying sensations attributed to witches as a drug-induced hallucination of the general sensibility of the body (Simon, 1888, p. 132). In an article cited by Piéron, Janet (1900-1901) explained illusions of levitation as occurring because of a hysterical loss of sensibility in the feet of a patient. With this speculation as a background, it is not surprising that some of the authors discussed in this article used physiological arguments related to changes in sensibility in their attempts to explain the phenomena dying persons had reported.

More recent researchers have followed up on the topic of panoramic memory (e.g., Noyes \& Kletti, 1977b; Stevenson \& Cook, 1995). Some of this work has focused on the experiences of people involved in accidents (e.g., Noyes \& Kletti, 1977a; Noyes \& Slymen, 1978-1979). To some extent Egger's ideas were similar to the later ideas of Pfister (1930), Ehrenwald (1974), and Noyes (1972; Noyes \& Kletti, 1976), who speculated that out-of-body and near-death experiences were a defense mechanism designed to deal with the threat of death. There 
are also similarities in Egger's and Sollier's ideas to more recent discussions about the distinction between physiologically- and psychologically-induced NDEs (e.g., Gabbard \& Twemlow, 1991; Owen, Cook, \& Stevenson, 1990; Stevenson, Cook, \& McClean-Rice, 1989-90).

Although the work of Egger, Féré, Sollier, and Piéron has been neglected by more recent students of the subject of panoramic memory and related phenomena near death, it is my hope that this short article will remind current students of the existence of this literature.

\section{References}

Abercrombie, J. (1832). Inquiries concerning the intellectual powers and the investigation of truth (3rd ed.). Edinburgh, Scotland: Waugh and Innes.

Agrillo, C. (2011). Near-death experiences: Out-of-body and out-of-brain. Review of General Psychology, 15, 1-10.

Alvarado, C. S. (2008). Note on Charles Richet's "La Suggestion Mentale et le Calcul Des Probabilités" (1884). Journal of Scientific Exploration, 22, 543-548.

Alvarado, C. S. (2009). Early and modern developments in the psychological approach to out-of-body experiences. In C. D. Murray (Ed.), Psychological scientific perspectives on out-of-body and near-death experiences (pp. 1-22). New York, NY: Nova Science.

Alvarado, C. S. (2010). Online resources for the history of out-of-body experiences and death-related phenomena. Journal of Near-Death Studies, 28(3), 143-162.

Asaad, G. (1990). Hallucinations in clinical psychiatry: A guide for mental health professionals. New York, NY: Brunner/Mazel.

Azam, Dr. [E. E.]. (1893). Hypnotisme et double conscience: Origine de leur étude et divers travaux sur des sujets analogues [Hypnotism and double consciousness: Origins of its study and various works about similar subjects]. Paris, France: Félix Alcan.

Barrow, J. (1847). An autobiographical memoir of Sir John Barrow, Bart., late of the Admiralty. London, England: John Murray.

Beard, G. B. (1877). A new theory of trance, and its bearings on human testimony. Journal of Nervous and Mental Disease, 4, 1-47.

Binet, A. (1892). Les altérations de la personnalité [Alterations of personality]. Paris, France: Félix Alcan.

Binet, A. (1897). État mental des mourants [The mental state of the dying]. L'Année Psychologique, 3, 629-637.

Binet, A., \& Féré, C. (1885). L’hypnotisme chez les hystériques: Le transfert [Hypnotism in hysterics: The transfer]. Revue Philosophique de la France et de l'Étranger, 19, 1-25.

Binns, E. (1842). The anatomy of sleep; or, the art of procuring sound and refreshing slumber at will. London, England: John Churchill.

Biondi, M. (2010). La life review nelle NDE second Ernesto Bozzano [The life review of NDEs according to Ernesto Bozzano]. The Missing Link, No. 4, 90-97. Retrieved from http://www.gruppogrima.it/library/ML04lug2010.pdf

Blackmore, S. J. (1993). Dying to live: Science and the near-death experience. London, England: Grafton. 
Bogousslavsky, J., \& Walusinski, O. (2011). Paul Sollier: The first clinical neuropsychologist. In J. Bogousslavsky (Ed.), Following Charcot: A forgotten history of neurology and psychiatry (Frontiers of Neurology and Neuroscience, 29, pp. 105-114). Basel, Switzerland: Karger.

Bonilla, E. (2011). Experiencias cercanas a la muerte: Revisión [Near-death experience: Review]. Investigación Clínica, 52, 69-99.

Bozzano, E. (1931). Indagini sulle manifestazioni supernormali [Investigation about supernormal manifestations] (Vol. 1). Città della Pieve, Italy: Dante.

Brierre de Boismont, A. (1845). Des hallucinations ou histoire raisonée des apparitions, des visions, des songes, de l'extase, du magnétisme et du somnambulisme [On hallucinations or a rational history of apparitions, visions, dreams, ecstasy, magnetism and sonambulism]. Paris, France: Germer Baillière.

Brittan, S. B. (1854). Man and his relations: Illustrating the influence of the mind on the body. New York, NY: W. A. Townsend.

Brooks, J. I. (1998). The eclectic legacy: Academic philosophy and the human sciences in nineteenth-century France. Cranbury, NJ: Associated University Presses.

Buffet, E. P. (1870). Is death painful? American and Continental Monthly, 1, 359-368.

Cardeña, E., \& Alvarado, C. S. (2011). Altered consciousness from the Age of Enlightenment through mid-20th century. In E. Cardeña \& M. Winkelman (Eds.), Altering consciousness: Multidisciplinary perspectives: History, culture and the humanities (Vol. 1, pp. 89-112). Santa Barbara, CA: ABC-CLIO.

Castel, P. H. (1998). La querelle de l'hystérie: La formation du discours psychopathologique en France (1881-1913) [The quarrel of hysteria: The formation of psychopathological discourse in France (1881-1913)]. Paris, France: Presses Universitaires de France.

Clarke, E. H. (1878). Visions: A study of false sight (pseudopia). Boston, MA: Houghton, Osgood.

Cobbe, F. P. (1877). The peak in Darien: The riddle of death. Littell's Living Age, 19(s.5), 374-379.

Crabtree, A. (1993). From Mesmer to Freud: Magnetic sleep and the roots of psychological healing. New Haven, CT: Yale University Press.

De Quincey, T. (1864). Confessions of an English opium-eater, and suspiria de profundis. Boston, MA: Tickner and Fields.

Derepas, G. (1883). Les theories de l'inconnaissable et les degrés de la connaissance [Theories of the unknowable and the degrees of knowledge]. Paris, France: Ernest Thorin.

de V., H. (1893). Correspondance et chronique: Les impressions d'un enseveli [Correspondence and chronicle: The impressions of a buried person]. Revue Scientifique, 51, 379-380.

Egger, V. (1877). La physiologie cérébrale et la psychologie physiologique [Cerebral physiology and physiological psychology]. Revue des Deux Mondes, 24, 193-244.

Egger, V. (1878). Sur les lapsus de la vision [On slips of vision]. Revue Philosophique de la France et de l'Étranger, 13, 286-289.

Egger, V. (1881). La parole intérieure: Essai de psychologie descriptive [The interior word: Essay of descriptive psychology]. Paris, France: Germer Baillière. 
Egger, V. (1895). La durée apparente des rêves [The apparent duration of dreams]. Revue Philosophique de la France et de l'Étranger, 20, 41-59.

Egger, V. (1896a). Le moi des mourants [The self of the dying]. Revue Philosophique de la France et de l'Étranger, 21, 26-38.

Egger, V. (1896b). Le moi des mourants: Nouveaux faits [The self of the dying: New facts]. Revue Philosophique de la France et de l'Étranger, 21, 337-368.

Ehrenwald, J. (1974). Out-of-the-body experiences and the denial of death. Journal of Nervous and Mental Disease, 159, 227-233.

Eliot, G. (1858). Scenes of clerical life. New York, NY: Harper \& Brothers.

Féré, C. (1887). Sensation et mouvement: Études expérimentales de psycho-mécanique [Sensation and movement: Experimental studies on psycho-mechanics]. Paris, France: Félix Alcan.

Féré, C. (1889). Note pour servir a l'histoire de l'état mental des mourants [Note for the history of the mental state of the dying]. Compte Rendu des Séances de la Société de Biologie, 9, 108-110.

Féré, C. (1892). La pathologie des émotions: Études physiologiques et cliniques [The pathology of emotions: Physiological and clinical studies]. Paris, France: Félix Alcan.

Féré, C. (1898). L'état mental des mourants [The mental state of the dying]. Revue Philosophique de la France et de l'Étranger, 45, 296-302.

Foschi, R. (2003). L'indagine sulla personalità alle origini della psicologia scientifica francese (1870-1885) [Research about personality in the origins of French scientific psychology (1870-1885)]. Physis, 40, 63-105.

Francis, J. R. (1896). The encyclopedia of death and life in the spirit-world (Vol. 1). Chicago, IL: Progressive Thinker.

Gabbard, G. O., \& Twemlow, S. W. (1991). Do "near death experiences" occur only near-death?-Revisited. Journal of Near-Death Studies, 10(1), 41-47.

Greyson, B. (2000). Near-death experiences. In E. Cardeña, S. J. Lynn, \& S. Krippner (Eds.), Varieties of anomalous experiences: Examining the scientific evidence (pp. 315-352). Washington, DC: American Psychological Association.

Greyson, B., Kelly, E. W., \& Kelly, E. F. (2009). Explanatory models for neardeath experiences. In J. M. Holden, B. Greyson, \& D. James (Eds.), The handbook of near-death experiences: Thirty years of investigation (pp. 213-234). Santa Barbara, CA: Praeger/ABC-CLIO.

Head, F. B. (1860). The horse and his rider. London, England: John Murray.

Heim, A. v. S. G. (1892). Notizen über den Tod durch Absturz [Notes on fatal falls]. Jahrbuch des Schweitzerischen Alpclub, 27, 327-337.

Herold, J. (1898). A manual of legal medicine for the use of practitioners and students of medicine and law. Philadelphia, PA: J. B. Lippincott.

Holden, J. M., Greyson, B., \& James, D. (2009). The field of near-death studies: Past, present and future. In J. M. Holden, B. Greyson, \& D. James (Eds.), The handbook of near-death experiences: Thirty years of investigation (pp. 1-16). Santa Barbara, CA: Praeger/ABC-CLIO.

Is death painful? (1870). Putnam's Magazine, 5(n.s.), 311-318.

Janet, P. (1886). Les actes inconscientes et la dédoublement de la personnalité pendant le somnambulisme provoqué [Unconscious acts and the doubling of personality during induced sonambulism]. Revue Philosophique de la France et de l'Étranger, 22, 577-592. 
Janet, P. (1892). L'anesthésie hystérique [Hysterical anesthesia]. Archives de Neurologie, 23, 323-352.

Janet, P. (1896). [Review of the article "Le Moi des Mourants," ("The Self of the Dying") by V. Egger]. Revue Neurologique, 4, 245-246.

Janet, P. (1900-1901). Une extatique [An ecstatic]. Bulletin de l'Institute Générale Psychologique, 1, 209-240.

Jung-Stilling, J. H. (1834). Theory of pneumatology. London, England: Longman, Rees, Orme, Brown, Green, and Longmans. (Original work published 1808)

Keller, A. (1896). L'état mental des mourants [The mental state of the dying]. Revue Philosophique de la France et de l'Étranger, 21, 311-313.

Larner, A. J. (2011). Charles Féré (1852-1907). Journal of Neurology, 258, $524-525$.

Lauvergue, H. (1842). De l'agonie et de la mort dans toutes les classes de la société sous le rapport humanitaire, physiologique et religieux [On agony and death in all the classes of society and its humanitarian, physiological and religious connections] (2 vols.). Paris, France: J.-B. Baillière.

Le Maléfan, P. (1995). Vécu de mort imminente et onirisme: Un chapitre inattendu de l'histoire de la psychologie dynamique [Experiences of imminent death and dreams: An unexpected chapter of the history of dynamic psychology]. Information Psychiatrique, 71, 773-780.

Leuba, J. H. (1902). Les tendances fondamentales des mystiques chrétiens [The fundamental tendencies of Christian mystics]. Revue Philosophique de la France et de l'Étranger, 27, 1-36.

Lewis, W. B. (1889). A text-book of mental diseases: With special reference to the pathological aspects of insanity. London, England: Charles Griffin.

Meletti Bertolini, M. M. (1991). Il pensiero e la memoria: Filosofia e psicologia nella "Revue philosophique" di Théodule Ribot (1876-1916) [Thought and memory: Philosophy and psychology in Théodule Ribot's "Revue philosophique" (1876-1916)]. Milan, Italy: Franco Angeli.

Memory. (1853). American Magazine of Homeopathy, 2, 249-251.

Mouilin, A. (1896). L'état mental des mourants [The mental state of the dying]. Revue Philosophique de la France et de l'Étranger, 21, 307-310.

Munk, W. (1887). Euthanasia: Or medical treatment in aid of an easy death. London, England: Longmans, Green.

Myers, F. W. H. (1892). On indications of continued terrene knowledge on the part of phantasms of the dead. Proceedings of the Society for Psychical Research, 8, 170-252.

Nicolas, S. (2002). Histoire de la psychologie française: Naissance d'une nouvelle science [History of French psychology: The birth of a new science]. Paris, France: In Press.

Noyes, R. (1972). The experience of dying. Psychiatry, 35, 174-184.

Noyes, R., \& Kletti, R. (1972). The experience of dying from falls. Omega: Journal of Death and Dying, 3, 45-52.

Noyes, R., \& Kletti, R. (1976). Depersonalization in the face of life-threatening danger: An interpretation. Omega: Journal of Death and Dying, 7, 103-114.

Noyes, R., \& Kletti, R. (1977a). Depersonalization in response to life-threatening danger. Comprehensive Psychiatry, 18, 375-384.

Noyes, R., \& Kletti, R. (1977b). Panoramic memory: A response to the threat of death. Omega: Journal of Death and Dying, 8, 181-194. 
Noyes, R., \& Slymen, D.J. (1978-1979). The subjective response to life-threatening danger. Omega: Journal of Death and Dying, 9, 313-321.

O., J. (1855). Replies to minor queries: Sensations in drowning. Notes and Queries, 12,500 .

Owen, J. E., Cook, E. W., \& Stevenson, I. (1990). Features of "near-death experience" in relation to whether or not patients were near death. Lancet, 336, 1175-1177.

Pfister, O. (1930). Shockgedanken und Shockphantasien bei höchster Todesgefahr [Shock thoughts and shock fantasies in extreme mortal danger]. Zeitschrift für Psychoanalyse, 16, 430-455.

Piéron, H. (1901). Sur l'interpretation des faits de rapidité anormale dans le processus d'évocation des images [On the interpretation of facts of abnormal speed in the process of image evocation]. In P. Janet (Ed.), IVe Congrès International de Psychologie (pp. 439-448). Paris, France: Félix Alcan.

Piéron, H. (1902). Contribution a la psychologie des mourants [Contibution to the psychology of the dying]. Revue Philosophique de la France et de l'Étranger, $27,615-616$.

Piéron, H. (1903). La rapidité des processus psychiques [The rapidity of psychic processes]. Revue Philosophique de la France et de l'Étranger, 28, 69-95.

Poulet, G. (1963). L'espace Proustien [Proustian space]. Paris, France: Gallimard.

Prichard, J. C. (1850). Somnambulism and animal magnetism. In J. Forbes, A. Tweedie, \& J. Conolly, revised by R. Dunglison (Eds.), The cyclopaedia of practical medicine (Vol. 4, pp. 194-211). Philadelphia, PA: Lea and Blanchard.

Reuchlin, M. (1964). Henri Piéron 18 juillet 1881-6 novembre 1964. Revue de Psychologie Appliquée, 14, 213-218.

Ribot, T. (1870). La psychologie anglaise contemporaine (École expérimentale) [Contemporary English psychology (Experimental school)]. Paris, France: Librairie Philosophique de Ladrange.

Ribot, T. (1881). Les maladies de la mémoire [The maladies of memory]. Paris, France: Germer Baillière.

Richer, P. (1885). Études cliniques sur la grande hystérie ou hystero-épilepsie [Clinical studies of the grand hysteria or hystero-epilepsy]. Paris, France: A. Delahaye and E. Lecrosnier.

Richet, C. (1883). La personnalité et la memoire dans le somnambulisme [Personality and memory during somnambulism]. Revue Philosophique de la France et de l'Étranger, 15, 225-242.

Richet, C. (1884). La suggestion mentale et le calcul des probabilités [Mental suggestion and the calculation of probabilities]. Revue Philosophique de la France et de l'Étranger, 18, 609-674.

Rosse, I. C. (1894). Death from submersion in its medico-legal relations. In R. A. Witthaus \& T. C. Becker (Eds.), Medical jurisprudence, forensic medicine and toxicology (Vol. 1; pp. 793-812). New York, NY: William Wood.

Sensations in drowning. (1853). National Magazine, 2, 335-336.

Sierra, M., \& Berrios, G. E. (1997). Depersonalization: A conceptual history. History of Psychiatry, 8, 213-229.

Simon, P. M. (1888). Le monde des rêves [The world of dreams] (2nd ed.). Paris, France: J. B. Baillière.

Sollier, P. (1892). Les troubles de la mémoire [The problems of memory]. Paris, France: J. Rueff. 
Sollier, P. (1893). Guide pratique des maladies mentales [Practical guide to mental illnesses]. Paris, France: G. Masson.

Sollier, P. (1896). L'état mental des mourants [The mental state of the dying]. Revue Philosophique de la France et de l'Étranger, 21, 303-307.

Sollier, P. (1900). Les problème de la mémoire [The problems of memory]. Paris, France: Félix Alcan.

Sollier, P. (1903). Sur le moi des mourants [On the self of the dying]. Bulletin de l'Institut Général Psychologique, 3, 29-32.

S., S. (1868). Experience of the drowned: A personal narrative. Bible Christian Magazine, 4(s. 4), 179-181.

Stevenson, I., \& Cook, E. W. (1995). Involuntary memories during severe physical illness or injury. Journal of Nervous and Mental Disease, 183, 452-458.

Stevenson, I., Cook, E. W., \& McClean-Rice, N. (1989-90). Are persons reporting "near-death experiences" really near death? A study of medical records. Omega: Journal of Death and Dying, 20, 45-54.

What drowning feels like. (1894). British Medical Journal, 2, 823-824.

Wiltse, A. S. (1889). A case of typhoid fever with subnormal temperature and pulse. St. Louis Medical and Surgical Journal, 57, 355-364.

Winslow, F. (1860). On obscure diseases of the brain, and disorders of the mind. London, England: John Churchill.

Wyld, G. (1881). Clairvoyance in relation to medicinal substances. Light, 1, 68.

Young, R. M. (1970). Mind, brain and adaptation in the nineteenth century: Cerebral localization and its biological context from Gall to Ferrier. Oxford, England: Clarendon Press. 